Prima: Jurnal Pendidikan Matematika

Vol. 5, No. 1, January 2021, pp. 64-71

P-ISSN: 2579-9827, E-ISSN: 2580-2216

Web: http://jurnal.umt.ac.id/index.php/prima

\title{
PROFILE OF STUDENT'S MATHEMATICAL PROBLEM SOLVING ABILITY BASED ON LINGUISTIC INTELLIGENCE AND MATHEMATICAL LOGICAL INTELLIGENCE
}

\author{
Hestu Wilujeng ${ }^{1}$, Edi Irawan ${ }^{2}$, Prahesti Tirta Safitri ${ }^{3}$, Aan Subhan Pamungkas ${ }^{4}$ \\ ${ }^{1,2}$ Institut Agama Islam Negeri Ponorogo, Jalan Pramuka no 133 Ponorogo, Indonesia \\ ${ }^{3}$ Universitas Muhammadiyah Tangerang, Jalan Perintis Kemerdekaan I/33 Tangerang, Indonesia \\ ${ }^{4}$ Universitas Sultan Ageng Tirtayasa, Serang Banten, Indonesia \\ e-mail: hestu@iainponorogo.ac.id
}

\begin{abstract}
The process of solving problems carried out by students in stages, namely understanding problems, planning solutions, carrying out solutions, and checking again. Solving student problems varies according to the basic characteristics of students' interests, talents, and potential. Learning will be more optimal if it is adjusted to the intelligence possessed by students. The goal is that teachers can facilitate learning according to students' intelligence, so the teacher must know the intelligence possessed by students. This research is a qualitative study using two subjects, namely the subject of linguistics and the subject of mathematical logic. The results showed that SLM completed using formulas at the problem-understanding stage, completed according to plan, and checked by recalculating. SL uses more trial-and-error reasoning, understanding information by reading sentences quickly, as well as checking again.
\end{abstract}

Keywords: problem-solving, linguistic intelligence, mathematical-logical intelligence

\begin{abstract}
Abstrak
Proses memecahkan masalah yang dilakukan siswa bertahap yaitu memahami masalah, merencanakan penyelesaian, melaksanakan penyelesaian dan memeriksa kembali. Penyelesaian masalah siswa berbeda-beda sesuai dengan karakter dasar yaitu minat, bakat dan potensi siswa. Pembelajaran akan lebih optimal jika disesuaikan dengan kecerdasan yang dimiliki oleh siswa. Tujuannya adalah guru dapat memfasilitasi pembelajaran sesuai dengan kecerdasan yang dimiliki oleh siswa maka guru harus mengetahui kecerdasan yang dimiliki oleh siswa. Penelitian ini merupakan penelitian kualitatif dengan menggunakan dua subyek yaitu subyek linguistik dan subyek logismatematis. Hasil Penelitian menunjukkan bahwa pada tahap pemecaham masalah, SLM menyelesaikan dengan menguunakan rumus, menyelesaikan sesuai rencana serta memeriksa dengan menghitung kembali. SL lebih menggunakan penalaran dengan coba-coba, memahami informasi dengan membaca kalimat secara cepat begitupun juga dalam memeriksa kembali.
\end{abstract}

Kata kunci: pemecahan masalah, kecerdasan linguistik, kecerdasan logis matematis

\section{INTRODUCTION}

Government regulation No. 22 of 2006 states that one of the objectives of junior high school mathematics learning is solving problems, including the ability to understand problems, design models, solve models and interpret the solutions obtained. These objectives emphasize the ability to solve problems and develop the ability to reason, think logically, systematically, critically, and carefully. Krulik and Rudnik (1995: 4) define problem-solving as a way that a person uses knowledge, skills, and understanding to meet an irregular situation's demands. Polya (1973) explains that in solving a problem, four steps must be taken: solving 
problems carried out by students in stages, namely understanding the problem, planning solutions, implementing solutions, and checking again.

Chatib (2009: 12) reveals that every person has basic characters, namely different potentials, interests, and talents. This difference affects a person in viewing and solving a problem. It means that the ability to solve problems depends on individual abilities related to one's intelligence. Gardner (in Jasmine, 2007: 14) states that everyone has at least eight intelligence types even though only a few are dominant. The intelligence referred to is linguistic intelligence, mathematical logical intelligence, kinesthetic intelligence, spatial intelligence, musical intelligence, interpersonal intelligence, intrapersonal intelligence, and naturalist intelligence.

Chatib (2009: 10) states that learning will be more optimal if adjusted to students' intelligence. The aim is that the teacher can facilitate learning according to students' intelligence, so the teacher must know the intelligence possessed by students. The learning process will be more optimal if the teacher's intelligence is the same as the intelligence of students. Even though the teacher will face many students with different dominant bits of intelligence in the classroom, the teacher must prepare learning that can facilitate all intelligence in developing thinking skills and problem-solving abilities when the teacher gives problems to math material.

Problem-solving is important to learn and is related to individual intelligence. In solving a problem, the character of thinking, experience, and knowledge makes a person carry out different problem-solving processes. Wilujeng (2019) states that it is possible to gain experience using the knowledge and skills they already have to apply to problem solving that is not routine through problem-solving students. Students can practice integrating the concepts and skills that have been learned. Students can be trained to make decisions because they have the skills to gather relevant information, analyze information, and realize how much it is necessary to re-examine the results they have obtained. Therefore, researchers want to know how students' actual abilities in solving math problems are reviewed based on students' linguistic intelligence and mathematical logical intelligence. 


\section{METHODS}

This research is a qualitative descriptive study because it aims to describe the mathematics problem-solving profile of grade VIII students based on multiple intelligences. The multiple intelligence instrument in this study was adopted from Prasetyo and Andriani (2009: 28).

Table 1. Research Subjects

\begin{tabular}{cll}
\hline Dominant Intelligence Possessed & Code & Score \\
\hline Linguistics & SL & 75 \\
Mathematical Logical & SLM & 70 \\
\hline
\end{tabular}

The researcher took two bits of intelligence, namely mathematical logical intelligence and linguistic intelligence, because these two bits of intelligence had the highest score compared to other intelligence when the researcher analyzed students using multiple intelligence instruments to SLM students and SL students. The triangulation used in this research is method triangulation, which compares the results of student work and the results of interviews on the first and second questions.

\section{RESULTS AND DISCUSSION}

\section{Profile of Mathematical Problem Solving in Mathematical Subjects (SLM)}

Data analysis to obtain SLM problem-solving profiles based on Polya stages as shown in Table 1 below,

Table 2. SLM Problem Solving Profiles

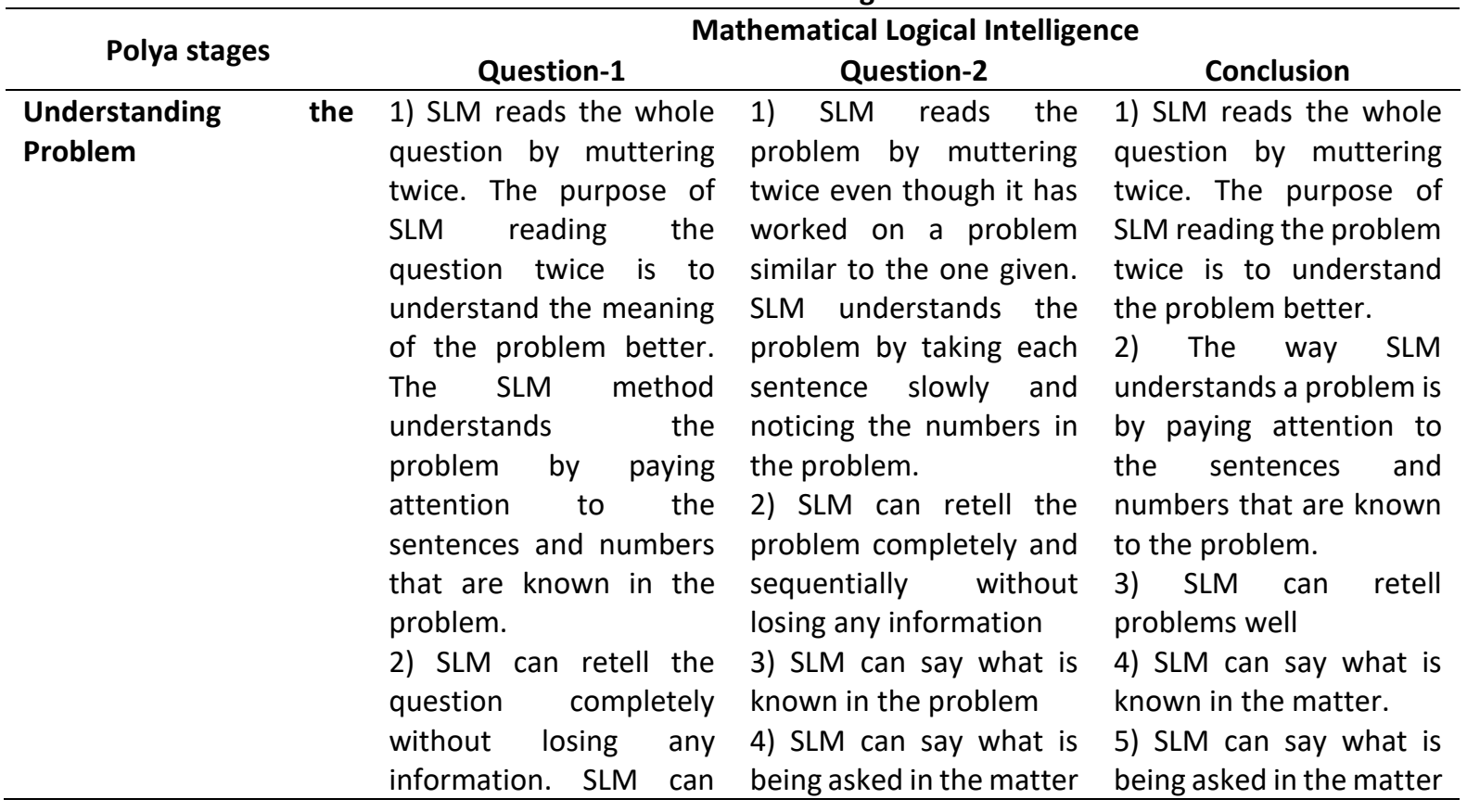


explain the meaning of grade 1 and grade 2 in the given problem, namely the seating level. 3) SLM can say what is known in the problem 4) SLM can say what to ask

Planning Problems

SLM uses all the information provided in the matter.

Checking the results of completion again provided, namely the
1) SLM plans to solve it by finding the number of seats in class 1 and class 2 from the information number and difference of seats. Next, multiply by the ticket price. In planning the completion, SLM tries to determine the number of seats in class 1 and class 2 .

2) SLM only plans one plan to solve the problem

3) SLM uses all the information provided in the matter.

1) SLM determines the number of seats in first class and second class by using algebra, although, in planning, SLM looks for the number of seats by trial and error.

2) SLM can solve and explain again the problem solving that has been done well

3) SLM solves problems in order and can be understood well

1) The way SLM checks the answer is by checking from the beginning of the calculation until you find the results

2) The goal of SLM is to check from front to back so that the sequence of steps to do it is then matched with what is known so that SLM is sure of the results of the answer.
1) SLM plans solutions using algebra and mathematical operations, namely addition, subtraction, division

2) SLM only plans one plan to solve the problem, namely algebra 3) SLM uses all the information provided in the matter.

1) SLM carries out the plan using algebra according to the completion plan, which is expressed at the planning stage

2) SLM can solve and explain solving problems that have been done well 3) SLM solves problems in order and can be understood well.

1) The way SLM checks the answer is by checking from the beginning of the calculation until you find the results

2) The goal of SLM is to check from front to back so that the sequence of the steps to do it is matched with what is known so that SLM is sure of the results of the answer.
1) SLM plans solutions using algebra and mathematical operations, namely addition, subtraction, multiplication, and division.

2) SLM only plans one plan to solve the problem, namely algebra.

3) SLM uses all the information provided in the matter.

1) SLM carries out the completion plan using algebra.

2) SLM can solve and explain again the problem-solving that has been done well.

3) SLM solves problems in order and can be understood well.

1) The SLM way to check the answer is by checking from the beginning of the calculation until you find the results.

2) The goal of SLM is to check from front to back so that the sequence of the steps to do it is matched with what is known so that SLM is sure of the results of the answer. 
2. Profile of Mathematical Problem Solving in Linguistic Subjects (SL)

Data analysis to obtain SL problem-solving profiles based on Polya stages as shown in Table 2 below,

Table 3. SL Problem Solving Profiles

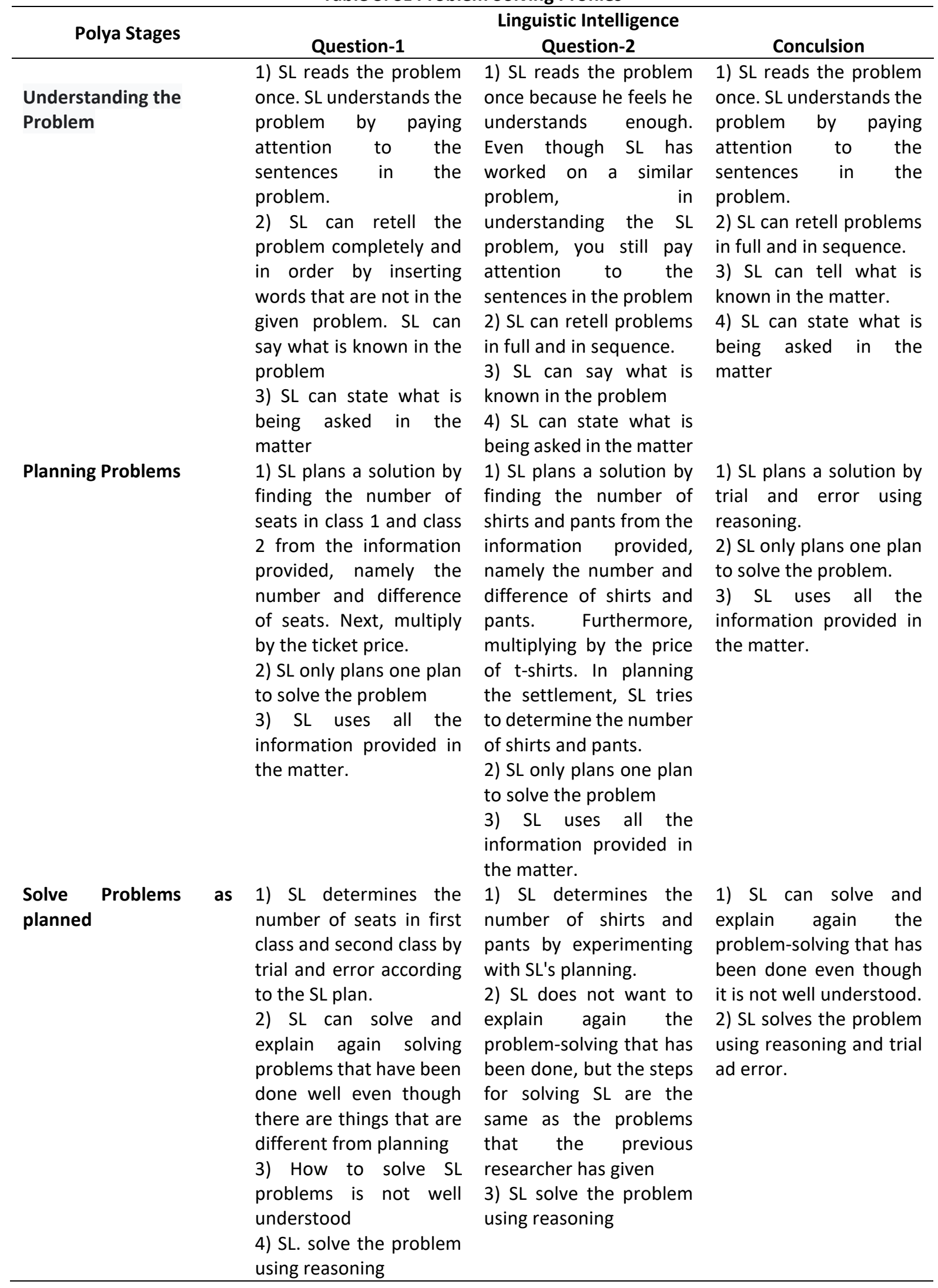




\begin{tabular}{ll}
\hline $\begin{array}{l}\text { Checking the results of } \\
\text { completion again }\end{array}$ & SL checks the answer SL checks the answer SL checks the answer \\
& from the start with a from the start with a from the start with a \\
& only in wishful thinking only in wishful thinking only in wishful thinking \\
& without writing or without writing or without writing or \\
& scribbling.
\end{tabular}

At the stage of understanding the problem, the characteristic of intelligence appears; namely, SLM is easier to understand the meaning of the problem by looking at numbers and sentences and reading twice to understand the meaning of the question better. SL subjects focused more on sentences and were able to re-express the questions well and in order. Following the research results by Mujib \& Mardiyah (2017), linguistics students can understand information from sentences while mathematical logic students better understand mathematical symbols in the problem.

In the stage of planning completion, SLM plans a solution using algebra and mathematical operations, namely addition, subtraction, multiplication, and division. SL plans a solution by trial and error using reasoning. Both subjects only used one completion plan. Wijaya, Kurnia H \& Sudarmin (2016) stated that students who have mathematical-logical intelligence could appropriately plan the solution. Riana, et al. (2017) stated that linguistic intelligence contains a person's ability to use language and words, both written and spoken, in various forms to express their ideas. Children who have linguistic intelligence to the maximum will improve their skills in reading, writing, building self-character, and speaking and listening, especially in public. Understand the meaning of the sentence.

In the stage of carrying out the completion according to the plan, SLM carries out the completion plan using algebra. SLM can solve and explain again the problem-solving that has been done well. SL can solve and explain the problem-solving that has been done even though it is not well understood because SL solves problems by using trial and error and reasoning. Wijaya, Kurnia H \& Sudarmin (2016) stated that students who have mathematical-logical intelligence could work following the problem-solving plan and are careful in compiling answers and systematically.

Polya's final stage is to check the results of the solution again. The SLM way to check the answer is by checking from the beginning of the calculation until you find the result. SLM's goal is to check from front to back so that the sequence of the steps to do it is matched with 
what is known so that SLM is sure of the results of the answer. SL checks the answers from the start with a quick look and counts only in wishful thinking without writing or scribbling. It is following the results of research by Toyib, Rohman, and Sutarni (2019); Ersoy and Guner (2015) state that at the stage of re-examining students who have mathematical-logical intelligence, these students re-read the questions from the beginning and do the recalculation to check the correctness of the calculation results of the subject then write the conclusions of the final results obtained. SL only glanced at it without recalculating.

The way SLM and SL in each stage solve mathematical problems with the Polya stage is under the characteristics of their intelligence. Every child is born with a different intelligence, and no student is stupid. Therefore, the surrounding environment, the learning process from parents and teachers can make children become individuals as reliable problem solvers not only in academics but also in their lives as long as the learning is in accordance with the characteristics of the child.

\section{CONCLUSION}

Based on the results and discussion above, this study concludes that SLM and SL complete problem solving according to their intelligence characteristics. SLM is faster in understanding problems by looking at the numbers in the questions, using plans, and completing by using formulas and checking again by crossing out and repeating calculations. SL emphasizes the meaning of the sentence, then trial and error in solving using reasoning, checking SL again, only skim reading without recounting. Suggestions related to this research are that before implementing learning, the teacher should identify each student's intelligence. The learning process will be more optimal if the teacher is able to facilitate the students' intelligence; The teacher should know the student's problem-solving profile so that it can be used as an evaluation to reduce errors and improve the learning process; The teacher trains students to provide reasons for each answer submitted so that students are accustomed to linking each problem with the knowledge they have.

\section{REFERENCES}

Chatib, Munif. (2009). Sekolahnya Manusia Sekolah Berbasis Multiple Intelligences di Indonesia. Bandung: Kaifa 
Ersoy, E., Guner, P. (2015). The Place of Problem Solving and Mathematical Thinking in The Mathematical Teaching. The Online Journal of New Horizons in Education, (5)(1), 120130.

Depdiknas. (2006). Peraturan Menteri Pendidikan Nasional No 22 Tahun 2006 tentang Standar Isi untuk Satuan Pendidikan Dasar dan Menengah. Jakarta: Depdiknas.

Gardner, Howard. (2003). Multiple Intelligences. Batam Centre: Interaksara.

Jasmine, Julia. (2007). Mengajar Berbasis Multiple Intelligences. Bandung: Nuansa Cendekia. Krulik, Stephen \& Rudnick, Jesse A. (1995). A New Sourcebook for Teaching Reasoning Problem Solving in Elementary School. Massachusetts: A Simon \& Schuster Company Moleong, Lexy. (2007). Metodologi Penelitian Kualitatif. Bandung: PT. Remaja Rosdakarya. Mujib \& Mardiyah. (2017). Kemampuan Berpikir Kritis Matematis Berdasarkan Kecerdasan Multiple Intelligences. Al-Jabar: Jurnal Pendidikan Matematika, Vol 8, No 2.

Prasetyo dan Andriani. (2009). Multiply Your Multiple Intelligences. Yogyakarta: Andi.

Polya, G. (1973). How to Solve It, A New Aspect of Mathematical Method. New Jersey: Princeton University Press.

Prawiradilaga, Dewi Salma dan Eveline Siregar. (2007). Mozaik Teknologi Pendidikan. Jakarta: Kencana.

Riana, Nanda dkk. (2017). Hubungan Antara Kecerdasan Linguistik Dengan Kecerdasan Logis Matematis Siswa Di Kelas V S D Negeri Lamreung Aceh Besar. Jurnal IImiah Pendidikan Guru Sekolah Dasar FKIP Unsyiah, Volume 2 Nomor 3, 15- 23.

Toyib, Rohman \& Sutarni. (2019). Kemampuan Pemecahan Masalah Matematika Model TIMSS Konten Bilangan Pada Siswa dengan Kecerdasan LogisMatematis Tinggi. Kontinu: Jurnal Penelitian Didaktik Matematika, Vol 3, No 2.

Wijaya, Kurnia H \& Sudarmin. (2016). Kemampuan Pemecahan Masalah Matematis Siswa Kelas VIII Berdasarkan Multiple Intelligence pada Setting PBL. Unnes Journal of mathematics Education Research.

Wilujeng, Hestu. (2019). Peningkatan Kemampuan Berpikir Aljabar Dan Multirepresentasi Matematis Serta Pencapaian Self Determination Siswa Smp Melalui Merril's First Principles of Instruction. Universitas Pendidikan Indonesia. Disertasi tidak dipublikasikan. 